\title{
Comparative Histological Study on the Effect of Stem Cells, and Gene Modified Stem Cells in Experimentally-Induced Diabetes Type 1 Cardiomyopathy
}

\author{
Original \\ Article \\ Sahar Gamal Abo ElFadl', Maha Shendi', Laila Ahmed Rashed ${ }^{2}$ and Ahmed Reda ${ }^{3}$ \\ ${ }^{1}$ Departments of Medical Histology and Cell Biology and ${ }^{2}$ Biochemistry, Faculty of Medicine, \\ Cairo University, Cairo, Egypt. \\ ${ }^{3}$ Faculty of Pharmacy, Near East University, North Cyprus, Cyprus
}

\begin{abstract}
Background and Objectives: Sarco(endo) plasmic reticulum $\mathrm{Ca}^{2+}$-ATPase (SERCA2a) is the ATP-driven pump that translocates $\mathrm{Ca}^{2+}$ from the cytoplasm to the lumen of the sarcoplasmic reticulum. $25 \%$ of children and adolescents with type 1 diabetes will develop diastolic dysfunction that results in part from a reduction in the activity of SERCA2a. The present study aimed at investigating and comparing the therapeutic effect of Adipose Mesenchymal Stem Cells (AMSCs) with SERCA2a gene modified AMSCs in diabetes type 1 induced cardiomyopathy of adult male albino rat.

Materials and Methods: Twenty-nine adult male albino rats were divided into: Donor group of 2 rats used to obtain AMSCs. Group I (Control group): 6 rats not exposed to diabetes induction. Group II (Diabetic group): 7 rats injected with streptozotocin (STZ) 50mg/Kg once. Group III ( (AMSCs group): 7 rats injected with AMSCs following induction of diabetes. Group IV (SERCA2a Modified AMSCs Group): 7 rats injected with SERCA2a modified AMSCs, following induction of diabetes. All rats were sacrificed 8 weeks from start of experiment.

Results: Morphological changes, indicating inflammation and degeneration, were found in the cardiac muscle of diabetic rats and regressed remarkably by AMSCs and SERCA2a modified AMSCs. The regression of morphological changes was confirmed by histological, immunohistochemical, morphometric and serological studies.

Conclusion: The therapeutic effect of SERCA2a modified AMSCs in diabetes type 1 cardiomyopathy was more remarkable than that of AMSCs.
\end{abstract}

Key Words: Adipose mesenchymal stem cells, cardiomyopathy, diabetes, SERCA2a

Revised: 3 May 2017, Accepted: 4 June 2017

Corresponding Author: Sahar Gamal Abo ElFadl, Tel.: +201125285784, E-mail: saharmg6161@gmail.com

ISSN: 2536-9172, June 2017, Vol. 1, No 1

\section{INTRODUCTION}

Type 1 diabetes mellitus (T1DM), is an autoimmunemediated disease characterized by selective destruction of insulin-producing pancreatic beta cells. Consequently, the need for lifelong administration of exogenous insulin for patient survival is the result ${ }^{[1]}$. The incidence of T1DM in children and adolescents is increasing steadily year by year and is presumably to be doubled by 2020 . Additionally, acute and chronic clinical complications could cause significant physical and mental trauma to the children with this disease ${ }^{[2]}$. Clinical and experimental studies have demonstrated evidence of diabetic cardiomyopathy independent of coronary artery disease and hypertension. Diabetic cardiomyopathy is strongly associated with adverse prognosis in adults ${ }^{[3]}$.
The sarco(endo)plasmic reticulum $\mathrm{Ca}^{2+}$-ATPase (SERCA2a) is the ATP-driven pump that translocates $\mathrm{Ca}^{2+}$ from the cytoplasm to the lumen of the sarcoplasmic reticulum. It is reported that $25 \%$ of children and adolescents with T1DM will develop diastolic dysfunction. This defect, which is characterized by an increase in time to cardiac relaxation, results in part from a reduction in the activity of SERCA2 $\mathrm{a}^{[4]}$.

Calcium transport by SERCA was found to be similar in stem cells-cardiac myocyte lines ${ }^{[5]}$. Mesenchymal stem cells (MSCs) are widely used for both allogeneic and autologous transplantations. The main sources of MSCs are bone marrow or adipose tissue. The latter source makes possible collection of higher cell numbers and plays a potential role as seeding cells in stem cell transplantation 
in animal models ${ }^{[6]}$. It was reported that lipid nucleic acid transfection reagents achieved delivery of their encoding DNA sequences through chemical transfection ${ }^{[7]}$.

\section{AIM OF THE WORK}

The present study aimed at investigating and comparing the therapeutic effect of AMSCs with SERCA2a gene modified AMSCs in diabetes type I induced cardiomyopathy of adult male albino rat.

\section{MATERIALS AND METHODS}

\section{Drug:}

Streptozotocin (STZ) was purchased from Sigma Company (St. Louis, Mo, USA) in a powder form as $1 \mathrm{~g}$ vial. The required dose was weighed using a digital scale and dissolved in citrate buffer.

\section{Experimental Design:}

This study was conducted on twenty nine adult male albino rats with average body weight 200 grams. They were housed in hygienic stainless steel cages and kept in clean well ventilated room in the Animal House of Physiology Department, Faculty of Medicine, Cairo University. They were allowed food and water ad libitum. All procedures were held according to the ethical guidelines of Cairo University.

The rats were divided into the following groups. Donor group: 2 rats were used to obtain AMSCs.

Group I (Control Group): It included 6 rats, that corresponded to and were sacrificed with the experimental groups II, III and IV respectively. The first two rats received a single intraperitoneal (IP) injection of $1 \mathrm{ml}$ citrate buffer and left for 8 weeks without therapy. The second two rats received a single IP injection of $1 \mathrm{ml}$ citrate buffer, 4 weeks later, each was given $0.5 \mathrm{ml}$ of phosphate buffered saline (PBS) intravenous (IV) via tail vein twice with 24 hours interval. The third two rats received citrate buffer and PBS as for the $2^{\text {nd }}$ two rats, in addition to $1.5 \mu 1$ lipofectamine IV. All control rats were sacrificed 8 weeks from the start of the experiment.

Group II (Diabetic Group): It included 7 rats. Diabetes was induced by a single IP injection of STZ at a dose of $50 \mathrm{mg} / \mathrm{kg}$ body weight ${ }^{[8]}$ dissolved in $0.5 \mathrm{ml}$ citrate buffer for each rat. Three days following STZ injection, diabetes was confirmed by measuring the blood glucose level in the Biochemistry Department, Faculty of Medicine, Cairo University. The animals were considered diabetic if their blood glucose level was higher than $200 \mathrm{mg} / \mathrm{dL}^{[9]}$. Cardiac injury was confirmed by measuring the creatine-kinase MB (CK-MB) serum level ${ }^{[10]} 24$ hours following STZ injection $^{[11]}$ in the Biochemistry Department, Faculty of Medicine, Cairo University. The rats were left for 8 weeks without therapy.
Group III (Adipose Mesenchymal Stem Cells Group): It included 7 rats that received STZ at the same dose and by the same route as in group II. Cardiac injury was confirmed as in group II. Four weeks following STZ injection, $0.5 \mathrm{ml}$ of cultured and PKH26-labeled adipose derived mesenchymal stem cells $(\mathrm{AMSCs})^{[12]}$, obtained from one of the donor's group rats, were suspended in PBS and injected in the tail vein ${ }^{[13]}$. The injection was performed on two successive days with 24 hours interval ${ }^{[14]}$. The 7 rats were left for another 4 weeks without therapy. The stem cell isolation, culture, labeling and phenotyping were performed at the Biochemistry Department, Faculty of Medicine, Cairo University.

Group IV (SERCA2a Modified Adipose Mesenchymal Stem Cells Group): It included 7 rats that received STZ at the same dose and by the same route as in group II. Cardiac injury was confirmed as in group II. Four weeks following STZ injection, $0.5 \mathrm{ml}$ of cultured, PKH26-labeled and SERCA2a gene transfected AMSCs were suspended in PBS and injected in the tail vein of the 7 rats. The injection was performed on two successive days. The 7 rats were left another 4 weeks without therapy.

The second rat of the donor group was used to prepare the transfected AMSCs. A part of cardiac muscle tissue was homogenized and processed for mRNA extraction followed by using reverse transcriptase (RT) for complementary deoxyribonucleic acid (cDNA) sequencing. Lipofectamine 3000 transfection $^{[15]}$ of cultured and labeled AMSCs by SERC2 $\mathrm{a}^{[16]}$ Was performed.

A) Isolation and propagation of AMSCs from rats ${ }^{[17 \text { and } 18]}$ :

Rats were euthanized with $\mathrm{CO}_{2}$, their abdomens were cut open and the adipose tissues were removed, washed with saline solution, collected and incubated in Dulbecco's modified Eagle's medium (DMEM) containing 0.2\% collagenase and $1 \%$ penicillin-streptomycin mixed solution (GIBCO/BRL) at $37 \mathrm{1C}$ for $40 \mathrm{~min}$. After the cell suspension was centrifuged (at $630 \mathrm{~g}$ for $10 \mathrm{~min}$ ), the fat layer found in the upper layer and the culture solution layer found in the middle layer were removed, and the stromal vascular fraction (SVF) obtained as a sediment was collected. Isolated nucleated cells were resuspended in complete culture medium supplemented with $1 \%$ penicillin-streptomycin DMEM (GIBCO/ BRL) supplemented with $10 \%$ fetal bovine serum (FBS). Cells were incubated at $37^{\circ} \mathrm{C}$ in $5 \%$ humidified $\mathrm{CO}_{2}$ for 12- 14 days as primary culture or upon formation of large colonies. When large colonies developed (80-90\% confluence), cultures were washed twice with phosphate buffer saline (PBS) and cells were trypsinized with $0.25 \%$ trypsin in $1 \mathrm{mM}$ (EDTA) (GIBCO/BRL) for 5 minutes at $37^{\circ} \mathrm{C}$. After centrifugation (at $2400 \mathrm{rpm}$ for 20 minutes), cells were resuspended with serum-supplemented medium and incubated in $50 \mathrm{~cm} 2$ culture flask (Falcon, USA). The resulting cultures were referred to as first-passage cultures. On day 14, the adherent colonies of cells were trypsinized, and counted. 
B) SERCA2a preparation and Lipofectamine 3000 transfection:

Cardiac muscle tissues were homogenized in a solution containing $(\mathrm{mM}) 250$ sucrose, 5 hydroxyethylpiperazineN'-2-ethanesulfonic acid, $10 \mathrm{NaN} 3$, and 0.2 phenylmethanesulfonyl fluoride, using a Polytron homogenizer. $\mathrm{Ca} 2+$-dependent $\mathrm{Ca} 2+-\mathrm{ATPase}$ activity in homogenates was measured at $37^{\circ} \mathrm{C}^{[19]}$. The data were analyzed by nonlinear regression with computer software (GraphPad Software). MSCs were plated at a confluency of $50 \%$ (500,000 cells/plate) one day prior to transfection. 1.5 $\mu 1$ Lipofectamine 3000 reagent (Invitrogen, USA) to 1.5 $\mu \mathrm{g}$ DNA (SERCA2a gene) were then used for transfection using serum-free DMEM. Culture media were changed 4 hours after transfection and replaced with DMEM $/ 10 \%$ FBS without antibiotics. The cells were then allowed to proliferate and differentiate in DMEM $/ 2 \% \mathrm{FBS}^{[20]}$. AMSCs cells were harvested during the $4^{\text {th }}$ passage and were labeled with PKH26 fluorescent linker dye ${ }^{[21]}$.

The animals of the experimental groups (groups II, III and IV) were also sacrificed 8 weeks from the start of the experiment. CK-MB was measured before sacrifice. Tail vein blood samples were collected for CK-MB cardiac enzyme estimation. The animals belonging to control and corresponding experimental groups were sacrificed by cervical dislocation ${ }^{[22]}$. A ventral midline incision was performed, the heart was exposed, rapidly dissected out, washed in saline. Cardiac muscle specimens were obtained from the ventricles and the apex of the heart and fixed in $10 \%$ formol saline for 24 hours. Paraffin sections were cut at $5 \mu \mathrm{m}$ thickness and exposed to the following studies:

\section{A) Histological Study:}

1- Hematoxylin and eosin ${ }^{[23]}$.

2- Masson's trichrome stain ${ }^{[24]}$.

\section{B) Fluorescent demonstration of PKH26-labeled} exogenous AMSCs ${ }^{[21]}$ :

\section{C) Immunohistochemical Study:}

1- Connexin (Cx) 43 immunostaining, for detecting gap junction proteins which form a hexamer to compose a connexon $^{[25]}$.

2- CD105 immunostaining, for detecting endogenous and exogenous undifferentiated AMSCs ${ }^{[26]}$.

\section{D) Morphometric Study:}

1- Area of dark nuclei

2 - Area $\%$ of collagen fibers

3 - Area $\%$ of Cx $43+$ ve discs

4- Area $\%$ of CD $105+$ ve cells

The previous studies were performed in Histology Department, Faculty of Medicine, Cairo University.

\section{E) Biochemical Analysis:}

1-Evaluation of formalin-fixed paraffin-embedded $(\boldsymbol{F F P E})^{[27]}$ cardiac muscle specimens by real time quantitative reverse transcription polymerase chain reaction
(qRT-PCR), for SERCA2a gene content estimation, was performed in Biochemistry Department. Reverse Transcription is carried out with the SuperScript FirstStrand Synthesis System for reverse transcriptase (RT)PCR. The following procedure is based on Invitrogen's protocol. The ribonucleic acid (RNA)/primer mixture was prepared in each tube: $5 \mu \mathrm{g}$ total RNA and $3 \mu \mathrm{l}$ random hexamers. The samples were incubated at $65^{\circ} \mathrm{C}$ for 5 min and then on ice for at least $1 \mathrm{~min}$. Reaction master mixture was prepared for each reaction then added to the RNA/primer mixture, mix briefly, and then placed at room temperature for 2 minutes. $1 \mu \mathrm{l}$ (50 units) of SuperScript II RT was added to each tube, mixed and incubated at $25^{\circ} \mathrm{C}$ for $10 \mathrm{~min}$. The tubes were incubated at $42^{\circ} \mathrm{C}$ for $50 \mathrm{~min}$, heat inactivated at $70^{\circ} \mathrm{C}$ for $15 \mathrm{~min}$, and then chilled on ice. $1 \mu \mathrm{l}$ RNAase $\mathrm{H}$ was added and incubated at $37^{\circ} \mathrm{C}$ for 20 min. The 1st strand complementary deoxyribonucleic acid (cDNA) was stored at $-20^{\circ} \mathrm{C}$ until use for real-time PCR. The primer concentrations were normalized, gene-specific and reverse primer pair were mixed. Each primer (forward or reverse) concentration in the mixture is $5 \mathrm{pmol} / \mu \mathrm{l}$. The PCR program was set up on ABI Prism standard deviation score (SDS) 7000. A copy of the setup file was saved and all PCR cycles were deleted (used for later dissociation curve analysis). $50^{\circ} \mathrm{C} 2 \mathrm{~min}, 1$ cycle, $95^{\circ} \mathrm{C} 10 \mathrm{~min}, 1 \mathrm{cycle}$, $95^{\circ} \mathrm{C} 15$ seconds $->60^{\circ} \mathrm{C} 30$ seconds $->72^{\circ} \mathrm{C} 30$ seconds, 40 cycles and $72^{\circ} \mathrm{C} 10 \mathrm{~min}, 1$ cycle. A real-time PCR reaction mixture can be either $50 \mu 1$ or $25 \mu \mathrm{l}$. After PCR is finished, the tubes were removed from the machine. The PCR specificity was examined by $3 \%$ agarose gel using $5 \mu \mathrm{l}$ from each reaction. The setup file was saved and the real-time PCR result was analyzed with the SDS 7000 software.

\section{Blood glucose level estimation:}

Blood sample from the tail vein of each rat was used to measure glucose level before sacrifice.

\section{F) Statistical Analysis:}

Quantitative data were summarized as means and standard deviations and compared using one-way analysisof-variance (ANOVA). Any significant ANOVA was followed by Bonferroni post-hoc test to detect which pairs of groups caused the significant difference. P-values $<0.05$ were considered statistically significant. Calculations were made on Social Package of Statistical Science (SPSS) software $16^{[28]}$.

\section{RESULTS}

\section{A) Histological results:}

\section{1- $H \& E$}

Examination of control sections revealed normal architecture. Cardiac muscle fibers were branched and arranged in various directions (Fig. 1-a). They exhibited pale oval nuclei and acidophilic sarcoplasm with nonclear striations (Fig. 1-b).In the diabetic group (group II) 
multiple congested vessels and widespread mononuclear cells were found among the muscle fibers (Fig. 1-c). Areas with multiple darkly stained nuclei, rarified sarcoplasm and homogenous material among the fibers were frequently encountered. In addition, multiple fibroblasts were clearly observed (Fig. 1-d).

On the other hand, assessment of sections in the group treated with AMSCs (group III) demonstrated less congestion and some mononuclear cells among the cardiac muscle fibers (Fig. 2-a). Moreover, some darkly stained nuclei were still observed among multiple pale nuclei and some fibroblasts (Fig. 2-b). However, sections of diabetic rats treated with SERCA2a modified AMSCs (group IV) demonstrated apparently normal muscle fibers with minimal congestion and few mononuclear cells (Fig. 2-c) with few darkly stained nuclei and most of the nuclei were pale (Fig. 2-d).

\section{Masson's trichrome}

In group I, fine collagen fibers were found around blood vessels and in between muscle fibers (Fig. 3-a) while in group II large amount of dense collagen fibers were observed among the muscle fibers of the diabetic rats (Fig. 3-b). In group III, collagen fibers were less dense in comparison to the diabetic group (Fig. 3-c). Collagen fibers showed further decrease in sections of group IV and became in the form of fine fibers around vessels and among the muscle fibers as well (Fig. 3-d).

\section{B) Fluorescent demonstration of PKH26-labeled exogenous AMSCs}

Sections of control (Fig. 4-a) and diabetic (Fig. 4-b) groups, didn't show any fluorescence among the cardiac muscle fibers. On the other hand, group III sections revealed multiple fluorescent labeled AMSCs (Fig. 4-c) while group IV sections demonstrated few fluorescent labeled SERCA2a modified AMSCs (Fig. 4-d).

\section{C) Immunohistochemical Results}

\section{Connexin 43 immunostaining}

Group I showed numerous +ve immunoexpression at the intercalated discs' connexons of serpeginous pattern (Fig. 5-a). The sections of group II revealed some +ve discs (Fig. 5-b). In the treated groups III (Fig. 5-c) and IV (Fig. 5-d) multiple + ve discs were evident all through the sections.

\section{CD 105 immunostaining}

Negative immunostaining was evident in all control sections (Fig. 6-a). In group II, few +ve spindle cells were seen inside congested blood vessels and in between the muscle fibers (Fig. 6-b). Group III rats demonstrated multiple +ve cells inside vessels and among the fibers as well (Fig. 6-c). In group IV, only some tve cells could be illustrated in the sections with the same distribution (Fig. 6-d).

\section{D) Morphometric Results}

The mean area of darkly stained nuclei showed a significant increase in the diabetic group in comparison to all other groups, while that of group III demonstrated a significant increase in comparison to group IV. There was a significant increase in the mean area $\%$ of collagen fibers of the diabetic group in comparison to all groups. The mean area \% of connexin $43+$ ve discs showed a significant decrease in the diabetic group compared to all other groups. Furthermore, group III showed a significant decrease in comparison to the control. Finally, the mean area \% of CD105 +ve cells of group III demonstrated a significant increase compared to the other groups, while that of group IV showed a significant increase compared to group II (Table 1).

\section{E) Biochemical Results}

The mean PCR values of SERCA2a gene content showed significant increase in group IV in comparison to groups II and III. On the other hand the mean blood glucose level before sacrifice demonstrated a significant increase in group II compared to all the other groups. The cardiac enzyme CK-MB mean values revealed significant elevation in all groups compared to the control when measured $24 \mathrm{hrs}$ after STZ injection. However, at sacrifice, CK-MB mean value of group II was found to be significantly increased in comparison to the other groups (Table 2). 
Table 1: Mean \pm SD of the area of dark nuclei, area $\%$ of collagen fibers, area $\%$ of connexin $43+$ ve discs and area $\%$ of $C D 105+$ ve cells

\begin{tabular}{|c|c|c|c|c|}
\hline Group & $\begin{array}{c}\text { Mean area of dark } \\
\text { nuclei }(\mu \mathrm{m})\end{array}$ & $\begin{array}{l}\text { Mean area } \% \text { of } \\
\text { collagen fibers }\end{array}$ & $\begin{array}{c}\text { Mean area } \% \text { of } \\
\text { connexin } 43+\text { ve discs }\end{array}$ & $\begin{array}{l}\text { Mean area } \% \text { of } \\
\text { CD105+ve cells }\end{array}$ \\
\hline Control (I) & - & $1.6 \pm 0.2$ & $12.2 \pm 2.4$ & - \\
\hline Diabetic (II) & $19.7 \pm 4.1 *$ & $20.3 \pm 1.9^{*}$ & $2.9 \pm 0.5 \#$ & $2.5 \pm 0.7$ \\
\hline Diabetic \& MSCs (III) & $4.3 \pm 0.9 * *$ & $3.1 \pm 0.5$ & $6.4 \pm 1.2 \# \#$ & $9.1 \pm 3.2^{\wedge}$ \\
\hline $\begin{array}{l}\text { Diabetic \& SERCA2a } \\
\text { MSCs (IV) }\end{array}$ & $0.9 \pm 0.1$ & $2.1 \pm 0.3$ & $10.7 \pm 1.3$ & $5.1 \pm 1.4^{\wedge \wedge}$ \\
\hline
\end{tabular}

*Significant increase compared to the other groups.

**Significant increase compared to group IV.

\# Significant decrease compared to the other groups. \#\#Significant decrease compared to control.

${ }^{\wedge}$ Significant increase compared to the other groups.

$\wedge^{\wedge}$ Significant increase compared to group II.

Table 2: Mean PCR values, blood glucose and serum CK-MB levels in control and experimental groups \pm SD

\begin{tabular}{|c|c|c|c|c|}
\hline Group & $\begin{array}{c}\text { PCR values of } \\
\text { SERCA2a gene }(\mu \mathrm{g})\end{array}$ & $\begin{array}{l}\text { Blood glucose level } \\
\text { measured before sacrifice } \\
(\mathrm{mg} / \mathrm{dL})\end{array}$ & $\begin{array}{c}\text { Serum CK-MB } \\
\text { measured } 24 \text { hours } \\
\text { following STZ } \\
\text { injections }(\mathrm{ng} / \mathrm{mL})\end{array}$ & $\begin{array}{l}\text { Serum CK-MB } \\
\text { measured before } \\
\text { sacrifice }(\mathrm{ng} / \mathrm{mL})\end{array}$ \\
\hline Group I & $1.83 \pm 0.3 \#$ & $110 \pm 5.5$ & $127 \pm 5.1^{*}$ & $135 \pm 5.4$ \\
\hline Group II & $0.27 \pm 0.03$ & $290 \pm 12.3 \#$ & $298 \pm 5.9$ & $305 \pm 10.8 \#$ \\
\hline Group III & $0.64 \pm 0.1 \mathbb{C}$ & $180 \pm 10.1$ & $294 \pm 11.1$ & $165 \pm 6.5$ \\
\hline Group IV & $1.25 \pm 0.2 \#$ & $135 \pm 18.1$ & $290 \pm 9.4$ & $132 \pm 7.3$ \\
\hline
\end{tabular}

\# Significant increase compared to other groups.

(C) Significant increase compared to group II.

*Significant decrease compared to other groups. 



Fig. 1: Photomicrographs of H \& E stained sections in the cardiac muscle of: a) a control rat showing branched muscle fibers (cmf) arranged in various directions (X200). b) a control rat showing pale oval nuclei $(\mathrm{N})$ and acidophilic sarcoplasm $(\mathrm{S})$ with non-clear striations (X400). c) a diabetic rat showing multiple congested vessels (C) and widespread mononuclear cells (M) among the muscle fibers (X200). d) a diabetic rat showing multiple darkly stained nuclei (d), rarified sarcoplasm (r), homogenous material (h) among the fibers, obvious congestion (C) and multiple fibroblasts (f) (X400).
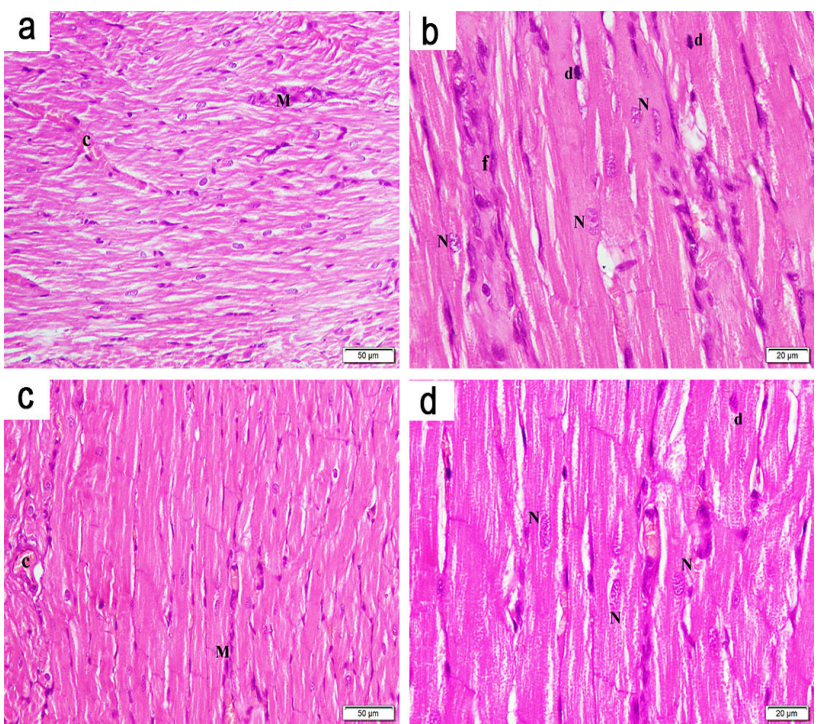

Fig. 2: Photomicrographs of H \& E stained sections in the cardiac muscle of: a) a diabetic rat treated with AMSCs showing less congestion (C) and some mononuclear cells (M) (X200). b) a diabetic rat with AMSCs showing some darkly stained nuclei (d), multiple pale nuclei (N) and some fibroblasts (f) (X400). c) a diabetic rat treated with SERCA2a modified AMSCs demonstrating apparently normal muscle fibers with minimal congestion (C) and few mononuclear cells (M) (X200). d) a diabetic rat treated with SERCA2a modified AMSCs demonstrating few darkly stained nuclei (d) and most nuclei are pale (N) (X400).
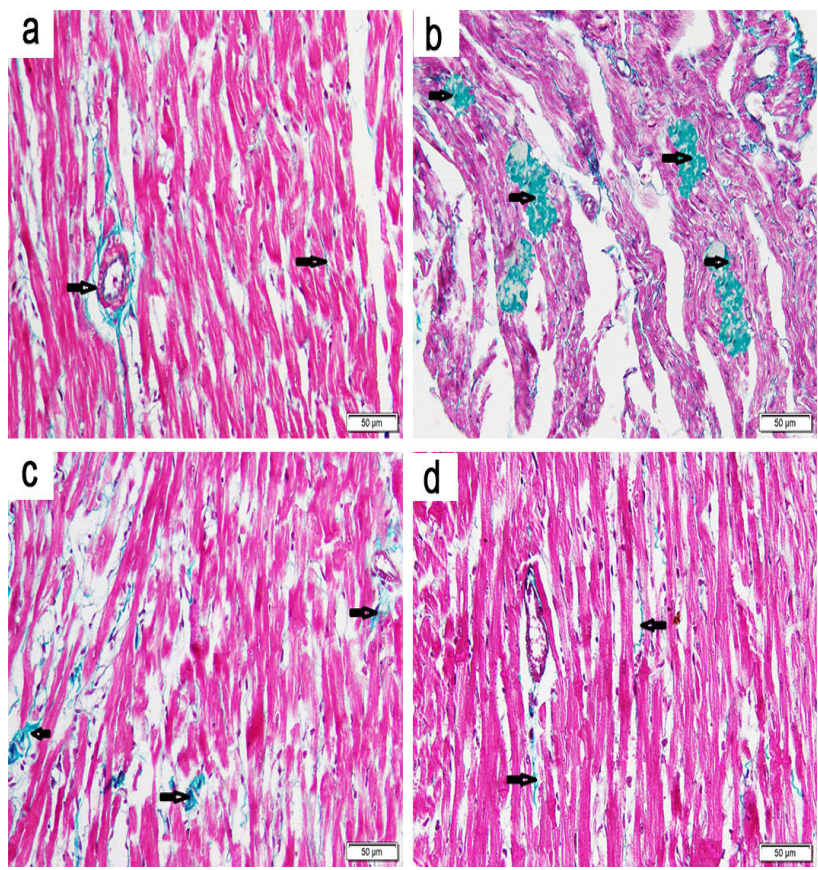

Fig. 3: Photomicrographs of Masson's trichrome stained sections (X200) in the cardiac muscle of: a) a control rat showing fine collagen fibers around a vessel and in between the muscle fibers (arrows). b) a diabetic rat showing multiple dense collagen fibers among the fibers (arrows). c) a diabetic rat treated with AMSCs demonstrating less dense collagen fibers (arrows). d) a diabetic rat treated with SERCA2a modified AMSCs showing fine collagen fibers around a vessel and among the fibers (arrows).


Fig. 4: Photomicrographs of PKH 26 stained sections (X100) in the cardiac muscles of: a) a control rat showing no fluorescence among the fibers (cmf) b) a diabetic rat showing no fluorescence c) a diabetic rat treated with AMSCs demonstrating multiple fluorescent labeled cells (arrows). d) a diabetic rat treated with SERCA2a modified AMSCs showing few labeled cells (arrows). 



Fig. 5: Photomicrographs of connexin 43 immunostained sections (X400) in the cardiac muscle of: a) a control rat showing numerous +ve discs (arrows). b) a diabetic rat showing some + ve discs (arrows). c) a diabetic rat treated with AMSCs demonstrating multiple +ve discs (arrows). d) a diabetic rat treated with SERCA2a modified AMSCs showing multiple +ve discs (arrows).

\section{DISCUSSION}

Streptozotocin-induced type I diabetic cardiomyopathy is a well-known complication and may eventually lead to life-threatening heart failure. In the current study, the therapeutic effect of AMSCs and that of gene modified AMSCs was evidenced by histological and immunohistochemical morphological changes and was confirmed by morphometric and serological findings that are going to be discussed.

In the present work, group II demonstrated multiple congested vessels, widespread mononuclear cells among the muscle fibers, homogenous material among the fibers and multiple fibroblasts. The previously mentioned findings indicated inflammatory changes developing in the myocardium secondary to type I diabetes. In accordance, a recent study ${ }^{[29]}$ referred all histological and functional impairment in case of diabetic cardiomyopathy to myocardial inflammation. In addition, triggers of inflammation could be activated advanced glycation end-products or damage-associated molecular pattern molecules. Therefore, the released cytokines create a state of low-grade chronic systemic inflammatory reaction including the heart. This promotes myocardial recruitment of monocytes and lymphocytes explaining the currently found increased mononuclear cell infiltration.

Multiple darkly stained nuclei, confirmed by a significant increase in the mean area, and rarified sarcoplasm were frequently encountered. These findings denoted degeneration of cardiac muscle fibers. In support, these changes were recently attributed to upregulation of reactive oxygen species (ROS) ${ }^{[30]}$. Furthermore, another group ${ }^{[31]}$ added and confirmed by proving that using a potent antioxidant as tiron could interfere with


. 6. P105 immunostained section (X200) in the cardiac muscle of: a) a control rat showing -ve immunostaining. b) a diabetic rat showing few +ve spindle cells inside a vessel (arrow) and between the fibers (arrowhead). c) a diabetic rat treated with AMSCs demonstrating multiple +ve cells in two vessels (arrows) and among the fibers (arrowhead). d) a diabetic rat treated with SERCA2a modified AMSCs showing some +ve cells in a vessel (arrows).

ROS pathway and hence prevents apoptosis-related cardiovascular diseases including diabetic cardiomyopathy.

In the present work, collagen fibers deposition was dense among multiple cardiac myocytes of the diabetic group. This observation has been confirmed by the significant increase in the mean area \% of collagen fibers. This is in agreement with a recent study ${ }^{[32]}$ that referred increased collagen content to the direct stimulatory effect of the inflammatory process on the cardiac fibroblast proliferation and collagen production. Concomitantly, it down regulates the secretion of protease inhibitors, thereby indirectly reducing the degradation of the extracellular matrix as well.

Group II revealed only some $\mathrm{Cx} 43+\mathrm{ve}$ intercalated discs, confirmed by a significant decrease in the mean area $\%$ of positive discs to investigate the integrity of intercellular gap junction protein present in the hexameric connexon hemi-channels at the discs. Moreover, this isomer has a rapid turnover rate compared to other cardiac proteins and hence represent an early and sensitive investigation tool. Going with, it was found that $\mathrm{Cx} 43$ localization became highly disorganized in diabetic hearts appearing wider and less linear. This could be correlated to the decrease in $\mathrm{Cx} 43$ tyrosine phosphorylation as diabetes progresses ${ }^{[33]}$.

In group II, few CD105 +ve spindle cells were seen inside congested blood vessels and in between the muscle fibers. They represent the endogenous MSCs rushing to the injured myocardium seeking repair of the damaged cells. In accordance, MSCs retrieved from bone marrow or adipose tissue hold great promise to enhance repair of damaged tissues. They exhibit a surface marker profile +ve for CD44, CD90 and CD105 ${ }^{[34]}$.

Group III, diabetic rats treated with AMSCs, 
demonstrated less congestion and some mononuclear cells among the cardiac muscle fibers in addition to some darkly stained nuclei observed among multiple pale nuclei and some fibroblasts. The mean area of darkly stained nuclei and the mean area $\%$ of collagen showed a significant decrease compared to group II. Multiple Cx43 +ve discs were evident, confirmed by a significant increase compared to group II. These findings denoted improvement of the degenerative and inflammatory changes. In accordance, it was proved that MSCs are widely used in the treatment of type 1 and type 2 diabetes mellitus because of their low-immunogenic and transdifferentiation characteristics in addition to their availability in many accessible tissues $^{[35]}$.

PKH26 stained sections of group III revealed multiple fluorescent labeled AMSCs. This confirms the migration of the injected cells to the affected cardiac tissue and the multiplicity denoted residual changes. In addition, multiple CD105 +ve AMSCs inside vessels and among the fibers, confirmed by a significant increase in the mean area $\%$ of CD105 +ve cells compared to the other groups, denotes activation of endogenous SCs by the injected cells. In agreement, it was declared that the benefits associated with adult stem cell therapy can be referred partially to activation of endogenous stem cell pool and enhancement of their homing to injury sites ${ }^{[36]}$.

Sections of diabetic rats treated with SERCA2a modified AMSCs (group IV) demonstrated apparently normal muscle fibers with minimal congestion and few mononuclear cells with few darkly stained nuclei and most of the nuclei were pale. In addition collagen content was comparable to the control. Multiple $\mathrm{Cx} 43$ +ve discs were evident, confirmed by a significant increase compared to groups II and III. This denoted a rapid and effective regenerative process. Going with, cellular stress and inflammatory reaction, as in diabetes, can affect the transcription of this gene and ultimately the myocardial integrity ${ }^{[37]}$.

PKH26 stained sections demonstrated few labeled SERCA2a modified AMSCs. Significantly reduced CD105 +ve cells were illustrated with the same distribution as in group III, yet the recovery is better confirmed by all the assessment parameters. This can be explained by the more pronounced transdifferentiation and higher efficiency of the SERCA2a modified AMSCs regenerative plasticity ${ }^{[38]}$.

A significant increase in the mean PCR values was detected in control and SERCA2a AMSCs compared to groups II and III, and in group III compared to group II. It was established that increase in SERCA2a gene expression is related to upregulated transcription and stability and provides homeostasis that leads to enhanced regeneration ${ }^{[39]}$

A significant decrease in the mean value of CK-MB was found in control compared to the experimental groups after 24 hours, confirming cardiac injury. While before sacrifice, a significant increase in the mean value of CKMB was detected in the non-treated group, indicating progression of cardiac damage, compared to control and treated groups. In accordance CK-MB was proved to be a sensitive indicator of cardiac injury ${ }^{[10]}$.

A significant decrease in the mean value of blood glucose level was evidenced in AMSCs and SERCA2a AMSCs groups. It was proved that mesenchymal stem cells modify the tissue microenvironment and promote the survival and regeneration of beta cell mass which controls the glycemic state more efficiently ${ }^{[40]}$.

\section{CONCLUSION}

In conclusion, the current data proved that the therapeutic effect of SERCA2a modified AMSCs in diabetes type I cardiomyopathy was more remarkable than that of AMSCs.

\section{CONFLICT OF INTEREST}

There are no conflicts of interest.

\section{REFERENCES}

1. Sanchez-Zamora YI, Juarez-Avelar I, VazquezMendoza A, Hiriart M and Rodriguez-Sosa $M$. Altered Macrophage and Dendritic Cell Response in Mif -/-Mice Reveals a Role of Mif for Inflammatory-Th1 Response in Type 1 Diabetes. J Diab Res 2016; 2016: 7053963 -7053981.

2. Sun C, Xue L, Zhu Z, Zhang F, Yang R, Yuan X, Jia $Z$ and Liu Q. Insights from lncRNAs Profiling of MIN6 Beta Cells Undergoing Inflammation. Mediat inflamm 2016; 2016: $9275106-9275115$.

3. Brunvand L, Fugelseth D, Stensaeth KH, DahlJorgensen $\mathrm{K}$ and Margeirsdottir HD. Early reduced myocardial diastolic function in children and adolescents with type 1 diabetes mellitus, a population-based study. BMC Cardiovasc Disord 2016; 16: 103- 107.

4. Shao CH, Capek HL, Patel KP, Wang M, Tang K, De Souza C, Nagai R, Mayhan W, Periasamy $\mathrm{M}$ and Bidasee KR. Carbonylation contributes to SERCA2a activity loss and diastolic dysfunction in a rat model of type 1 diabetes. Diabetes 2011; 60(3): 947- 959.

5. Hwang HS, Kryshtal DO, Feaster TK, SánchezFreire V, Zhang J, Kamp TJ, Hong CC, Wu JC and Knollmann BC. Comparable calcium handling of human iPSC- derived cardiomyocytes generated by multiple laboratories. J Mol Cell Cardiol 2015; 85:79-88. 
6. Zhang W, Schmull S, Du M, Liu J, Lu Z, Zhu $\mathrm{H}$, Xue S, Lian F. Estrogen Receptor $\alpha$ and $\beta$ in Mouse: Adipose-Derived Stem Cell Proliferation, Migration, and Brown Adipogenesis In Vitro. Cell Physiol Biochem 2016; 38(6): 2285- 2299.

7. Zuris JA, Thompson DB, Shu Y, Guilinger JPBessen JL, Hu JH, Maeder ML, Joung JK, Chen ZY and Lin DR. Cationic lipid mediated delivery of proteins enables efficient protein based genome editing in vitro and in vivo. Nat Biotechnol 2015; 33(1): 73- 80 .

8. Hidaka R, Machida M, Fujimaki S, Terashima $\mathrm{K}$, Asashima $\mathrm{M}$ and Kuwabara T. Monitoring neurodegeneration in diabetes using adult neural stem cells derived from the olfactory bulb. Stem Cell Res Ther 2013; 4(3): 51 -61.

9. Bhansali S, Kumar V, Saikia UN, Medhi B, Jha V, Bhansali A and Dutta P. Effect of mesenchymal stem cells transplantation on glycaemic profile and their localization in streptozotocin induced diabetic Wistar rats. Indian J Med Res 2015; 142(1): 63- 71 .

10. Sheta A, Elsakkar M, Hamza M and Solaiman A. Effect of metformin and sitagliptin on doxorubicininduced cardiotoxicity in adult male albino rats. Hum Exp Toxicol- 2016; 35 (11): 1227- 1239.

11. Radhiga T, Rajamanickam C, Senthil $\mathrm{S}$ and Pugalendi KV. Effect of ursolic acid on cardiac marker enzymes, lipid profile and macroscopic enzyme mapping assay in isoproterenol- induced myocardial ischemic rats. Food Chem Toxicol. 2012; 50(11): 3971- 3977.

12. Sheashaa H, Lotfy A, Elhusseini F, Abdel Aziz A, Baiomy A, Awad S, Alsayed AH, El-Gilany A, Saad MA, Mahmoud K, Zahran F, Salem DA, Sarhan A, Ghaffar HA and Sobh M. Protective effect of adipose-derived mesenchymal stem cells against acute kidney injury induced by ischemiareperfusion in Sprague-Dawley rats. Exp Ther Med. 2016;11(5): 1573 -1580.

13. Bassiony HS, Zickri MB, Metwally HG, ElSherif HA and Alghandour SM. Comparative Histological Study on the Therapeutic Effect of Green Tea and Stem Cells in Rat Model of Alzheimer's Disease Complicating Diabetes. MD Thesis.2016: 56- 74.

14. Aboul-Fotouh GI, Zickri MB, Metwally HG, Ibrahim IR and Kamar SSI. Comparative Study on the Therapeutic Effect of Atorvastatin and Stem Cells on Amiodarone Induced Lung Injury in Male Rat. MD Thesis 2016: 53- 76.
15. Mars T, Strazisar M, Mis K, Kotnik N, Pegan K, Lojk J, Grubic Z and Pavlin M. Electrotransfection and lipofection show comparable efficiency for in vitro gene delivery of primary human myoblasts. $\mathrm{J}$ Membr Biol. 2015; 248(2): 273 -283.

16. Hayward C, Patel H and Lyon A. Gene therapy in heart failure: SERCA2a as a therapeutic target. Circ J 2014; 78(11): 2577- 2587.

17. Takehara Y, Yabuuchi A, Ezoe K, Kuroda T, Yamadera R, Sano C, Murata N, Aida T, Nakama $\mathrm{K}$, Aono F, Aoyama N, Kato K and Kato O. The restorative effects of adipose-derived mesenchymal stem cells on damaged ovarian function. Lab Invest. 2013; 93(2): 181 -193.

18. Espina M, Jülke H, Brehm W, Ribitsch I, Winter K and Delling U. Evaluation of transport conditions for autologous bone marrow-derived mesenchymal stromal cells for therapeutic application in horses. Peer J. 2016; 4: 1773- 1795.

19. Tupling AR, Bombardier E, Gupta SC, Hussain $\mathrm{D}$, Vigna $\mathrm{C}$, Bloemberg $\mathrm{D}$, Quadrilatero J, Trivieri MG, Babu GJ, Backx PH, Periasamy M, MacLennan DH and Gramolini AO. Enhanced $\mathrm{Ca} 2+$ transport and muscle relaxation in skeletal muscle from sarcolipin-null mice. Am J Physiol Cell Physiol. 2011; 301(4): 841- 858.

20. Jackson MF, Hoversten KE, Powers JM, Trobridge GD and Rodgers DB. Genetic manipulation of myoblasts and a novel primary myosatellite cell culture system: comparing and optimizing approaches. FEBS J. 2013; 280(3): 827- 844.

21. Ude CC, Shamsul BS, Ng MH, Chen HC, Norhamdan MY, Aminuddin BS and Ruszymah BHI. Bone marrow and adipose stem cells can be tracked with PKH26 until post staining passage 6 in in vitro and in vivo. Tiss Cell 2012; 44: $156-163$.

22. Kumar B, Kannan M and Quine D. Litsea Deccanensis ameliorates myocardial infarction in Wistar Rats: Evidence from biochemical and histological studies. J Young Pharm. 2011; 3(4): 287-296.

23. Kiernan JA. Histological and Histochemical methods: Theory and Practice, third edition, Arnold publisher, London, New York and New Delhi. 2001: 111 -162.

24. Bancroft JD and Gamble M. Connective tissue stains. In: Theory and Practice of Histological Techniques, $6^{\text {th }}$ edition. Elsevier Health Sciences, 
Churchill Livingstone, Edinburgh, London, Oxford, New York, Philadelphia, St Louis, Sydney and Toronto. 2008: 150.

25. Wang K, Xu BC, Duan HY, Zhang H and Hu FS. Late cardioprotection of exercise preconditioning against exhaustive exercise-induced myocardial injury by up-regulatation of connexin 43 expression in rat hearts. Asian Pac J Trop Med.2015; 8(8): $658-663$.

26. Steinert AF, Kunz M, Prager $P$, Göbel S, Klein-Hitpass L, Ebert R, Nöth U, Jakob $\mathrm{F}$ and Gohlke F. Characterization of bursa subacromialis-derived mesenchymal stem cells. Stem Cell Res Ther 2015; 6: 114- 127.

27. Pu T, Guo P, Qiu Y, Chen S, Yang L, Sun L, Ye F and $\mathrm{Bu} \mathrm{H}$. Quantitative real-time polymerase chain reaction is an alternative method for the detection of HER-2 amplification in formalin-fixed paraffinembedded breast cancer samples. Int J Clin Exp Pathol. 2015; 8(9): 10565- 10574

28. Emsley R, Dunn G and White I. Mediation and moderation of treatment effects in randomized controlled trials of complex interventions. Stat Meth Med Res. 2010; 19(3): 237 -270.

29. Frati G, Schirone L, chimenti I, Yee D, Biondi-Zoccai $\mathrm{G}$, Volpe $\mathrm{M}$ and Sciarretta $\mathrm{S}$. An overview of the inflammatory signaling mechanisms in the myocardium underlying the development of diabetic cardiomyopathy. Cardiovasc Res. 2017; 113(4): 378 -388.

30. Yang F, Yu X, Li T, Wu J, Zhao Y, Liu J, Sun A, Dong S, Wu J, Zhong X, Xu C, Lu F and Zhang W. Exogenous H2S regulates endoplasmic reticulummitochondria cross-talk to inhibit apoptotic pathways in STZ-induced type I diabetes. Am J Physiol Endocrinol Metab. 2017; 3(1): 190- 203.

31. Jiang $\mathrm{P}$, Zhang D, Qiu H, Yi X, Zhang Y, Cao Y, Zhao B, Xia Z and Wang C. Tiron ameliorates high glucose-induced cardiac myocyte apoptosis by PKC $\delta$-dependent inhibition of osteopontin. Clin Exp Pharmacol Physiol. 2017; Apr 10. doi: 10.1111/1440-1681.12762. [Epub ahead of print].
32. Zhang Y, Wang JH, Zhang YY, Wang YZ, Wang J, Zhao Y, Jin XX, XueGL, Li PH, Sun YL, Huang QH, Song XT, Zhang ZR, Gao X, Yang BF, Du ZM and Pan ZW. Deletion of interlukin-6 alleviated interstitial fibrosis in streptozotocininduced diabetic cardiomyopathy of mice through affecting TGFbeta 1 and miR-29 pathways. Sci Rep. 2016; 6: 23010.

33. Joshi MS, Mihm MJ, Cook AC, Schanbacher $\mathrm{BL}$ and Bauer JA. Alterations in connexin 43 during diabetic cardiomyopathy: Competition of tyrosine nitration versus phosphorylation. J Diabetes. 2015; 7(2):250- 259.

34. Li S, Huang KJ, Wu JC, Hu MS, Sanyal M, HU M, Longaker MT and Lorenz HP. Peripheral blood-derived mesenchymal stem cells: candidate cells responsible for healing criticalsized calvarial bone defects. Stem cells Transl Med, 2015; 4(4): 359- 368

35. Gurusamy N. The potential of Mesenchymal Stem Cells in diabetes mellitus. Diabesity 2017; 3(1): 1- 4 .

36. Penn M S. The Unraveling of the Matryoshka Doll. Circ Res, 2017; 120: 1075 -1077.

37. Lee A, Oh J, Gorski P A, Hajjar R and Kho C. Post-translational Modifications in Heart Failure: Small Changes, Big Impact. Heart Lung Circ. 2016; 25(4): 319-324.

38. MishraPK, YingW, NandiSS, Bandyopadhyay GK, PatelKKandMahataSK.Diabetic Cardiomyopathy: An Immunometabolic Perspective. Front Endocrinol., 2017; 8(72): $1-12$.

39. Wenjing $\mathrm{H}$, Tongda $\mathrm{X}$, Pei W, Defeng P, Junhong C, Jing C, Buchun Z, Hong Z and Dongye L. Luteolin improves cardiac dysfunction in heart failure rats by regulating sarcoplasmic reticulum Ca2+-ATPase 2a. Sci Rep, 2017; 7: 41017.

40. Gerace D, Wilks RM, Nassif NT, Lal S, Steptoe R, 4 and Simpson AM. CRISPR-targeted genome editing of mesenchymal stem cell-derived therapies for type 1 diabetes: a path to clinical success? Stem Cell Res Ther. 2017; 8: 62 
الملخص العربى

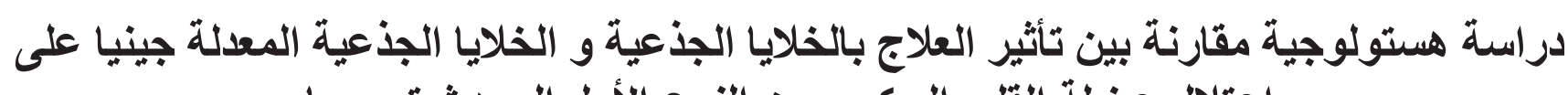

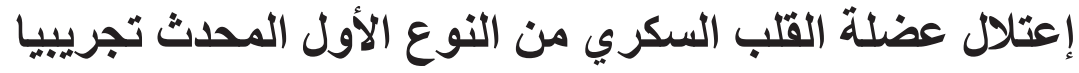

سحر جمال أبو الفضل1 ، مها شندي1، ليلى راشد² وأحمد رضا3

1قسم علم الأنسجة الطبية وبيولوجيا الخليةو الكيمياء الحيوية ـ كلية الطب - جامعة القاهرة،

3كلية الصيدلة ـ جامعة الشرق القريب ـ قبرص الشمالية ـ قبرص

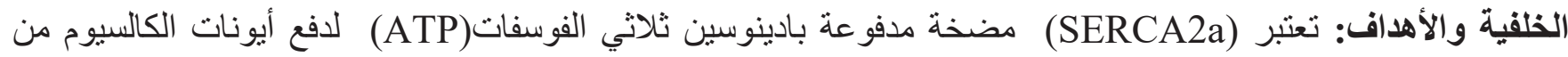

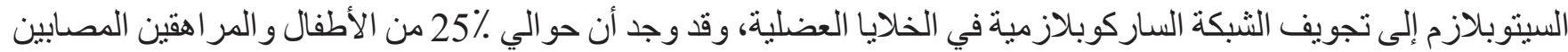

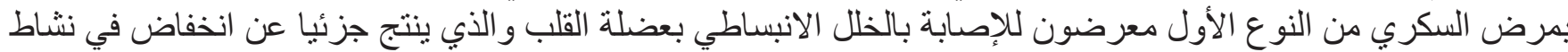
SERCA2a

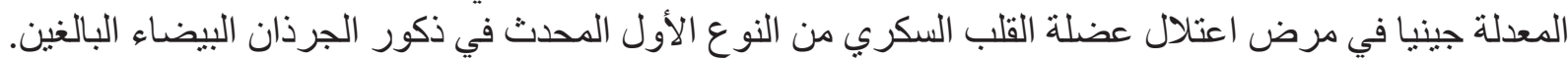

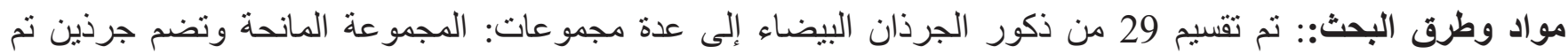

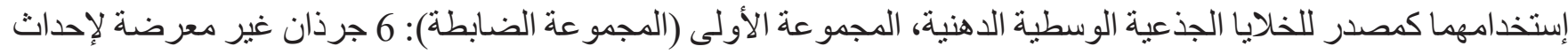

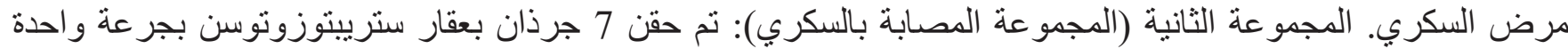

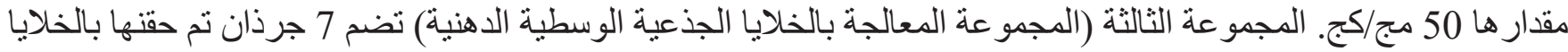

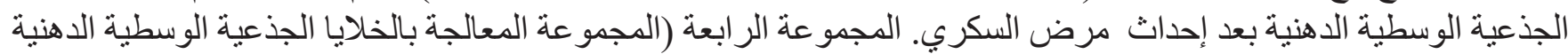

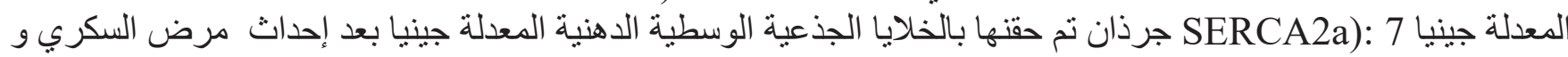
تم ذبح جميع الجرذان بعد مرور 8 أسابيع من بداية التجرئة

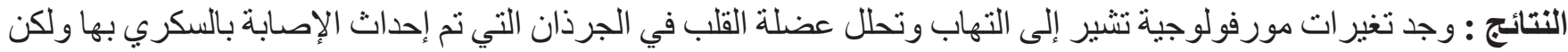

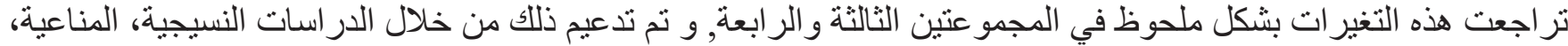

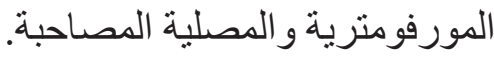
الإستنتاج : كان التأثير العلاجي للخلايا الجذعية المعدلة جينيا SERCA2a مميز ا وأفضل من العلاج بالخلايا الجذعيةالوسطية

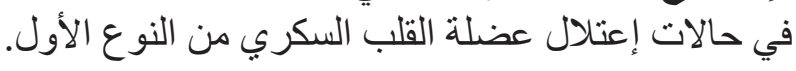



